\title{
Species Composition, Relative Abundance and Habitat Association of Birds in Nansebo Forest, South Eastern Ethiopia
}

\author{
Ziyad Jemal $^{1} \quad$ Mustefa Sultan Dalu ${ }^{2}$ \\ 1.Oromia Forest and Wildlife Enterprise, Ethiopia \\ 2.College of Agriculture and Environmental Science, Arsi University Asella, Ethiopia
}

\begin{abstract}
A study on avian species composition, relative abundance, and habitat association at Nansebo forest was carried out from June 2017 - February 2018 during wet and dry seasons. To collect data for the study, the whole habitat of the study area was divided into dominant vegetation types. Accordingly, habitat of the study area was divided into moist Afromontane forest and modified habitat in Nansebo forest. A line transects count aided by binocular was employed to investigate avian species diversity, relative abundance and Habitat association. Therefore 20 transect lines of $1 \mathrm{~km}$ lengths with a width of $0.25 \mathrm{~km}$ or less were used to cover $27.75 \%$ of the area in Nansebo forest. A total of 105 bird species of which 1 endemic, 8 near endemics, 1 globally threatened and 9 Palearctic migrants were recorded in Nansebo forest. Species richness and abundance varied between the three and two habitats. There was significant difference in species richness among habitats $(\mathrm{F} 1,18=94.657 \mathrm{P}=0.000)$ in Nansebo forest. In Nansebo forest the highest Shannon-Wiener diversity index $\left(\mathrm{H}^{\prime}=4.17\right)$ recorded from the modified habitat. It can be concluded that both area has high species diversity including endemics and endangered species. It can also be good potential for bird watching tourism that can integrate economic gain with biodiversity conservation. Hence, urgent conservation measures and further detail research is recommended to conserve the bird species.
\end{abstract}

Key words/Phrases: Avian species, Habitat types, Species richness, Species similarity

DOI: $10.7176 /$ ALST/74-03

Publication date:May $31^{\text {st }} 2019$

\section{INTRODUCTION}

\section{Background and Justification}

Ethiopia is a country with a wide range of climatic, geographical and topographic features. These have contributed to the richness in biodiversity and endemism (Yalden and Largen, 1992; Jacobs and Schloeder, 2001).It has rich biodiversity resources of which 2970 species are animals and between 6,500- 7,000 higher plants consisting of $12 \%$ endemics (EBI, 2015). Of the animal species 320 are mammals of which 36 are endemics, 926 bird species consisting of 24 endemics, 1,249 arthropods with 11 endemics, 200 fish with 40 endemics, 202 reptiles with 17 endemics and 73 amphibians with 30 endemics (EBI, 2015 and Weldemariam Tesfahunegny, 2016). Of these, birds are one of the most important components of biodiversity with ecological, economic and esthetic values. Birds are known as efficient and cost-effective insect pest controllers, Fruit-eating birds help in dispersal of seeds and seeds may sprout wherever the droppings fall and certain birds like hummingbirds and sunbirds pollinate flowers that produce nectar. Birds through the ages have been the source of considerable fascination and folklore and have been used as symbols (Clout and Hay, 1989).

The distribution and abundance of many bird species are determined by the composition of the vegetation or habitat (Lee and Rotenberry, 2005). Birds select habitats that fit their requirements for successful reproduction and survival though some generalist species may utilize several habitats (Rodríguez-Estrella, 2007). Besides habitat size, foraging modes and floristic composition have influence in the distribution of the species differences in requirement among bird species have caused specificity on habitat requirement (Buckley and Freckle ton, 2010).

Chance and Walsh (2006) indicated that, birds respond to changes in vegetation composition and structure, which in turn affects their food resources. For example, Mountain plover (Charladies mountainous) feeds primarily on insects (grasshoppers, crickets, beetles, flies, ants); uses ground for nesting and prefer short grass while Mongolian sand plover (Charladies atrifrons) feeds on invertebrates (mollusks, worms, crustaceans especially crabs and insects); uses tree for nesting and prefer shore of the lakes. Therefore, habitats either terrestrial or aquatic restrict bird species distribution and diversity (Buckley and Freckle ton, 2010).

In most habitats, plant communities determine the physical structure of the environment, and therefore, have a considerable influence on the distributions, abundance and diversity of birds and interactions of other animal species. Habitat features such as floristic complexity, cover and density of vegetation are also the important factor in bird's habitat selection (Casas et al., 2016). For example, for bird species diversity in forest, Tees et al. (2004) evidenced that, the physical structure of a plant community, i.e. how the foliage is distributed vertically, may be more important than the actual composition of plant species.

Despite the rich bird assemblages in Ethiopia, due to enormous habitat degradation and fragmentation many 
bird species including the endemic are threatened (Girma Mengesha et al., 2011). Particularly, expansion of agriculture, livestock encroachment, deforestation, illegal fire, by the ever increasing human population has been often cited as the major cause of bird's habitat degradation, fragmentation and loss in Ethiopia ultimately affecting the survival of birds (Sekercioglu et al., 2012).

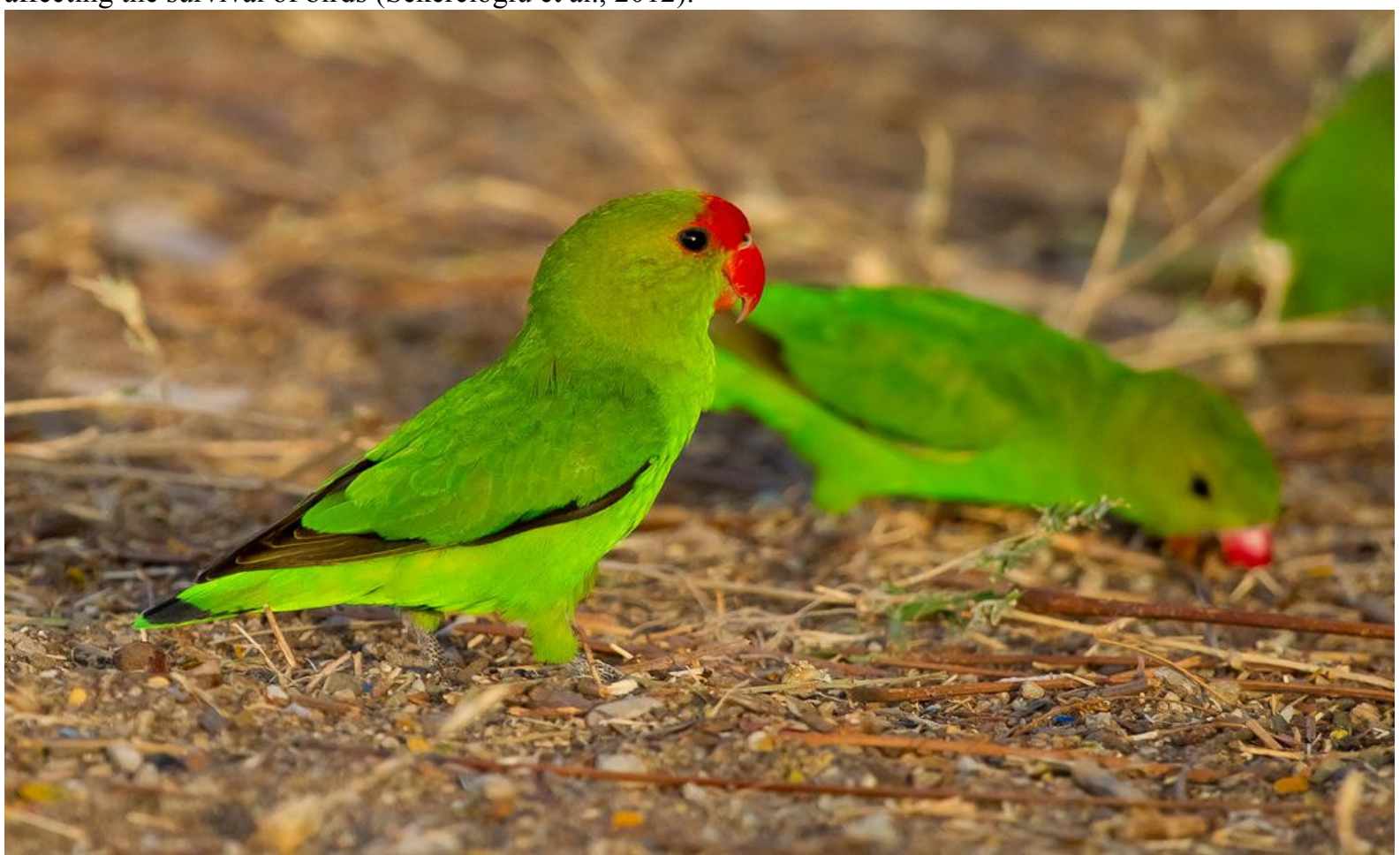

Figure 1. Black winged Love bird

\section{Statement of the Problem}

Currently, due to land uses changes it is difficult to find forest habitat covering large areas. Most of the land has been converted to settlement and farmlands.

Though no immediate threat is foreseen to the avian population, it could be resulted in deleterious effect on the overall ecosystem. Moreover, it is extremely important in areas where anthropogenic activities are major factors threatening the survival of the bird species. It has also been indicated that threats such as deforestation and livestock encroachments affect the abundance and distribution of birds as it affects the cover and food requirement (Girma Mengesha et al., 2011).

Several studies have linked habitat structure and composition, as well as landscape structure, to changes in avian populations, which have implications to reserve planning and management practices (Fuller et al., 2007; St-Laurent et al., 2007 and Girma Mengesha et al., 2011). Studies by McCain, 2009 and Waterhouse et al., 2002 have attempted to model species-habitat relationships. Understanding such patterns and their underlying mechanisms is critically important not only for knowledge but also for conservation efforts (Sisay Hailu, 2008).

Other studies from different parts of the world focused on characterizing the bird's species composition and abundance on specific regions of the country (Girma Mengesha and Afework Bekele, 2008). There are a few isolated reports of bird species diversity outside of protected areas in Ethiopia (Aerts et al., 2008), although there is better documentation of birds in protected areas (EWNHS, 1996). Comprehensive baseline information is lacking even for several of the endemic bird species. The status of birds in relation to Habitat association in the present study areas is very little known. As a result, the present study is aimed to investigate bird Habitat association in Nansebo forest thus contributes to the conservation of the species in the area.

\section{MATERIALS AND METHODS}

\section{Description of the Study Area}

The study was conducted at the Nansebo remnant forest in Nansebo district in Oromia regional state respectively (Fig.1).

\section{Geographical Location}

Nansebo district is one of the districts in the west Arsi Zone of Oromiya regional state of Ethiopia (Fig.1). Nansebo is bordered on the North by Dodola district, on the South by Borena Zone Girja district, on the North 
east by Adaba district, on the West by Sidama Zone Chiri district, on the Northwest by Kokosa District, on the East by Bale Zone Harana Buluk District. Nansebo district is located in between $6^{\circ} 10^{\prime}-6^{\circ} 40^{\prime} \mathrm{N}$ and $39^{\circ} 0^{\prime}-$ $39^{\circ} 40^{\prime} \mathrm{E}$ (Fig.1). Nansebo district is located at about $407 \mathrm{~km}$ far from Addis Ababa and $134.5 \mathrm{~km}$ away from Shashemene, the capital city of the zone.

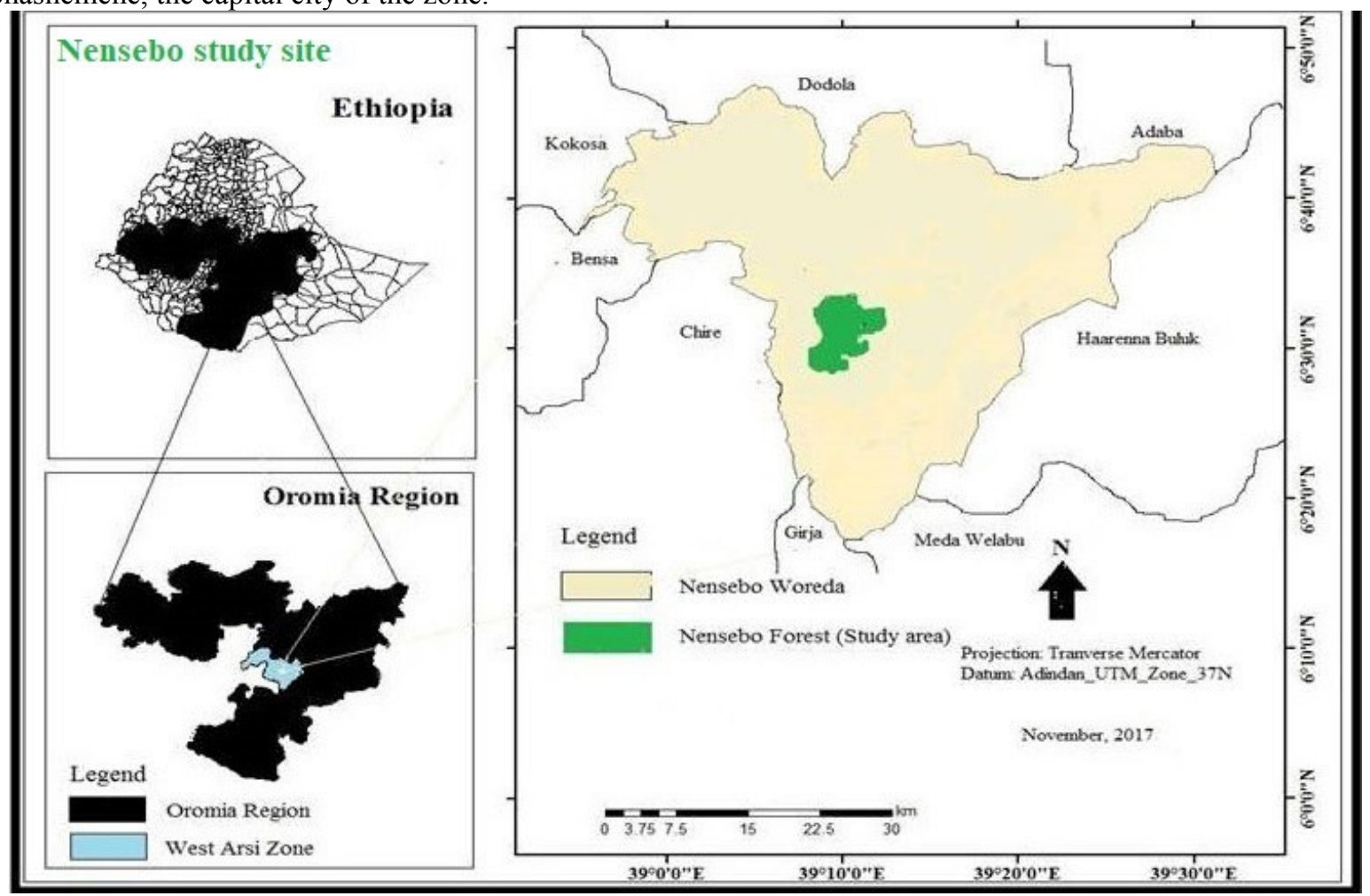

Figure 2: Location Map of Study Area

\section{Topography and Climate}

Nansebo district is characterized by mountainous landscape having an altitude ranges from $1500 \mathrm{~m}$ a.s.1 to 3700 $\mathrm{m}$ a.s.1 . The district exhibits bimodal rainfall pattern. The annual rain fall ranges between 900 to $1100 \mathrm{~mm}$ with a temperature that varies between a minimum of $15 \mathrm{C}^{\circ}$ and a maximum $22 \mathrm{C}^{\circ}(\mathrm{NWAO}, 2012)$.

\section{Flora and Fauna}

Nansebo forest is predominately characterized by moist Afromontane Forest. In Nansebo the most commonly found tree and shrub species in study area are Eucalyptus camaldulensis, Coffee arabica, Cordia africana, Grevillea robusta, Sesbania sesban, Junipures procera, Croton macrostachys, Albizia gummifera, Leucaena leucocephala, Hygenia abyssinica, Vernonia amygdelina, Rhamnus sprinoids, Prunus africana, Cupressus lusitanica, Olea africana and fruits like Mangifera indica, Psidium guajava, Citrus sinensis, Persea americana, Citrus limon and shrub species planted or grown naturally on farmlands, home gardens and forest lands (NWAO, 2012).

In Nansebo forest, Leopard (Panthera pardus), Grey duiker (Sylvicapra grimmia), Spotted hyena (Crocuta crocuta), Common warthog (Phacochoerus africanus), Anubis baboon (Papio anubis), Colobus monkey (Colobus geureza) and Crested porcupine (Hystrix cristata) and avifauna such as, Thick billed raven (Galerida theklae), Dusky turtle dove ( Tockus alboterminatus), Black winged love bird (Agapornis taranta), Brown wood warbler (Phylloscopusum brovirens), Abyssinian slaty fly catcher (Melaenornis chocolatina) are some of birds found in the study area (NWCTO,2014).

\section{Socio Economic Activity}

Nansebo District has a total population of 114,559 of whom 56,976 are men and 57,583 are women; 6,068 or $5.3 \%$ of its population are urban dwellers (ECSA, 2007).

A survey of the land in Nansebo district shows that $22 \%$ is arable or cultivable (11\% was in annual crops), $18.5 \%$ pasture, $58 \%$ forest and shrub land, and the remaining $1.5 \%$ is considered swampy, degraded or otherwise unusable). The major livestock reared in the area were Cattle, Sheep, Goats, Mules, Beekeeping, Donkeys, Horses and Poultry (NWAO, 2012). 


\section{Methods}

\section{Reconnaissance Survey}

A reconnaissance survey was carried out during the second week of June, 2017 for about one week to have basic information on accessibility, topography, infrastructures, and habitat stratification based on vegetation distribution and topographic nature for Nansebo forest. Furthermore, pilot survey was conducted at both study areas to test the applicability of the survey method, before the commencement of the actual data collection. For the pilot survey three transects in Nansebo forest was laid down and data collection was carried out.

\section{Sampling Design}

For this study, the Nansebo forest was stratified into two habitat types (modified habitat and Moist Afromontane forest) based on altitudinal ranges and vegetation types.

In Nansebo forest, the modified habitat consisted of scattered tree species of Podocarpus falcatus, Acacia species and Eucalyptus species, occurs from 1882-2153m asl. Moist Afromontane forest represents altitude areas between $2186-2392 \mathrm{~m}$ asl, with dominant stands of the indigenous tree species such as Croton macrostachys, Strychnos spinosa, Clematis longicauda, Prunus africana and Millettia ferruginea. The Moist Afromontane forest was relatively intact and undisturbed compared with modified habitat.

Based on the reconnaissance survey, sampling transects was systematically generated in a geographic information system (GIS) using ArcGIS software v. 10.1 (ESRI, 2012) in the Nansebo forest. The total area of Nansebo forest were $1135,0000 \mathrm{~m}^{2}(11,350 \mathrm{ha})$. Of these $27.75 \%$ (3150 ha) of the area were sampled in Nansebo forest. A stratified random sampling technique was employed in which transect placement was proportional to the area of the habitat types and represents each of the habitat types (Bibby et al., 1998, Shimelis Aynalem and Afework Bekele, 2008). Accordingly, a total of 20 transects, of which five transects in modified habitat while the rest fifteen (15) transects were used in Moist Afromontane forest to estimate the species diversity, relative abundance and Habitat association of birds in Nansebo forest (Fig. 2). The distance between two adjacent transects was $1 \mathrm{~km}$ in Nansebo forest.The length of each transect line was $1 \mathrm{~km}$ with a width of $0.25 \mathrm{~km}$ or less in Nansebo forest. To avoid edge effect, transect lines were spaced $500 \mathrm{~m}$ in Nansebo forest from the road side (edge of the forest). Line transect method was used since the study area is accessible and species can be detected along transect line. With line transect method it is possible to cover large areas and can generate more species richness efficiently (Bibby et al., 1992). Therefore, this method is very important since comprehensive baseline information and status of bird species in Nansebo forest is lacking.

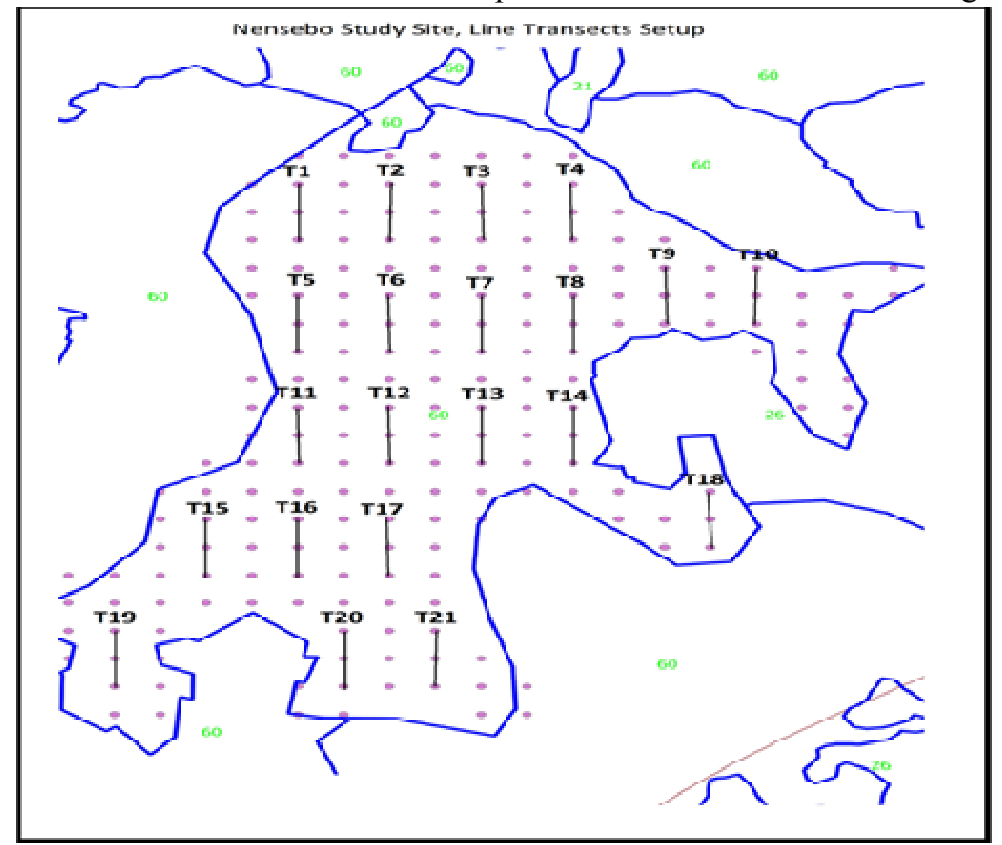

Figure 3: Line Transect Layout of the Study Area

\section{Method of Data Collection}

Data collection was carried out on foot walking along transect lines. Bird identifications and counting of individuals conducted by direct observations aided with naked eye and binoculars (10x50). Sound records and photography were also taken for further confirmation by using Digital Camera. The associated vegetation types were also described and recorded. Location and distance of the observed birds was determined and recorded along transect lines using Geographic positioning system (GPS). Each day of survey, arrive at the starting point 
approximately 20 minutes before sunrise so that counting can begin at sunrise to minimize the effect of time and weather conditions on bird detectability. Birds were counted when they were active in the mornings from 06:30 10:00 $\mathrm{h}$ and in the afternoon from 15:30-18.00 $\mathrm{h}$ (Bibby et al., 1992). Unfavorable weather (strong wind or rain) was also being considered. A bird flying over the area was observed and recorded on data gathering worksheets to identify for species richness.

For identification of species, plumage pattern, size, shape, color, songs and calls were considered as important parameters (Afework Bekele and Shimelis Aynalem, 2009). Songs and calls were also used for identifying nocturnal species.

Supplementary data, such as elevation above sea level, latitude and longitude, vegetation type, average vegetation height of perching site for birds and percent slope inclination (flat Clinometers (Zerihun Girma et al., 2015).

\section{Method of Data Analysis}

Moreover, Sorenson's similarity Coefficient (SOR) was equally calculated between pairs of habitats as: SOR = $2 \mathrm{a} /(2 \mathrm{a}+\mathrm{b}+\mathrm{c})$ (Kent and Coker, 1992). Where $\mathrm{a}=$ number of species common to both habitat; $\mathrm{b}=$ number of species unique to habitat 1 ; and $\mathrm{c}=$ number of species unique to habitat 2 .

The step wise regression analysis (backward elimination technique) model was carried out on the bird species richness and abundance both in wet and dry season as the outcome variable to evaluate parameters of the habitats that account for their disproportionate use. Model selection was based on $\mathrm{F}$ and $\mathrm{P}$ values. DurbinWatson statistic (D-W) and Variance inflation factor (VIF) were used to examine autocorrelation and multicollinearity of the predictor variables. Backward elimination continued until the "minimum F-to-remove" dropped below the specified probability level (0.1). All computations were done by using SPSS version 20 and Past3 software 1.0 was used to calculate diversity indices.

\section{RESULTS}

\section{Species Composition and Relative Abundance}

A total of 1076 individuals of birds classified into 15 orders, 45 families and 105 species were recorded from Nansebo forests (Appendix 1). Among the recorded species, Wattled ibis (Bostrychia carunculata), Thick billed raven (Corvus crassirostris), Black winged love bird (Agapornis taranta), Ethiopian cisticola (Cisticola lugubris), Abyssinian oriole (oriolus monacha), Abyssinian slaty flycatcher (Chocolatina ficedula), Abyssinian wood pecker (Abyssinicus phylloscopus) and Banded Barbet (Lybius undatus) were endemic to Ethiopia and Eritrea in Nansebo forest. The endemic Yellow-fronted Parrot (Poicephalus flavifrons) was also recorded from Nansebo forest.

One globally threatened bird species was recorded; of which one, Hooded vulture (Psophocichla litsipsirupa) is endangered and two Rougets rail (Onychognathus morio) and Semi collared flycatcher (Semi torquata) were near threatened bird species ( IUCN red list, 2016) (Appendix 1).In Nansebo forest 96 bird species were resident whereas 9 were Palearctic migrants' species (Appendix 1).In Nansebo forest the highest number of bird species was recorded from the family Sylviidae (10 species) followed by Accipitridae ( 8 species), Columbidae ( 7 species) and Cisticolidae (6 species) (Appendix 1).

Based on the percent relative abundance computation, Abyssinian oriole (Oriolus monacha) $(6.92 \%)$ was the most abundant bird species when all habitat types considered together in Nansebo forest (Appendix 1).

\section{Sorensen's Bird Species Similarity Index among the Three Habitat Types in Different Seasons}

In Nansebo forest the minimum value (0.662) of bird species similarity between Moist Afromontane forest and modified habitat was recorded in wet season and the maximum value was calculated during the dry season count with a value of 0.881 (Table 1).

Table 1: Bird species similarity of Nansebo among the habitat types and seasons

\begin{tabular}{lcccc}
\hline & \multicolumn{3}{c}{ Modified } & Moist Afromontane forest \\
\cline { 2 - 5 } Habitat types & Dry & Wet & Dry & Wet \\
\hline Modified & - & - & & - \\
Moist Afromontane forest & 0.881 & 0.662 & - & \\
\hline
\end{tabular}

\section{Habitat Association}

The vegetation height classes at interval of $0-5 \mathrm{~m}$ had the highest number of average species richness $(19.65 \pm$ 3.61, $\mathrm{N}=23$ ) and individuals (109.1 9.53, $\mathrm{N}=23$ ) in Nansebo forest (Fig.3). In Nansebo forest vegetation height classes at interval of $11-15 \mathrm{~m}$ had the least average species richness $(2.67 \pm 0.31, \mathrm{~N}=58)$ and individuals per plot $(8.8 \pm 2.32, \mathrm{~N}=58)$ (Fig. 3).

There was significant difference in average species richness $(F 5,58=6.578, \mathrm{p}=0.000)$ and individuals $(\mathrm{F} 5$, $58=27.36, \mathrm{p}=0.000)$ between the vegetation height classes and bird species in Nansebo forest. 


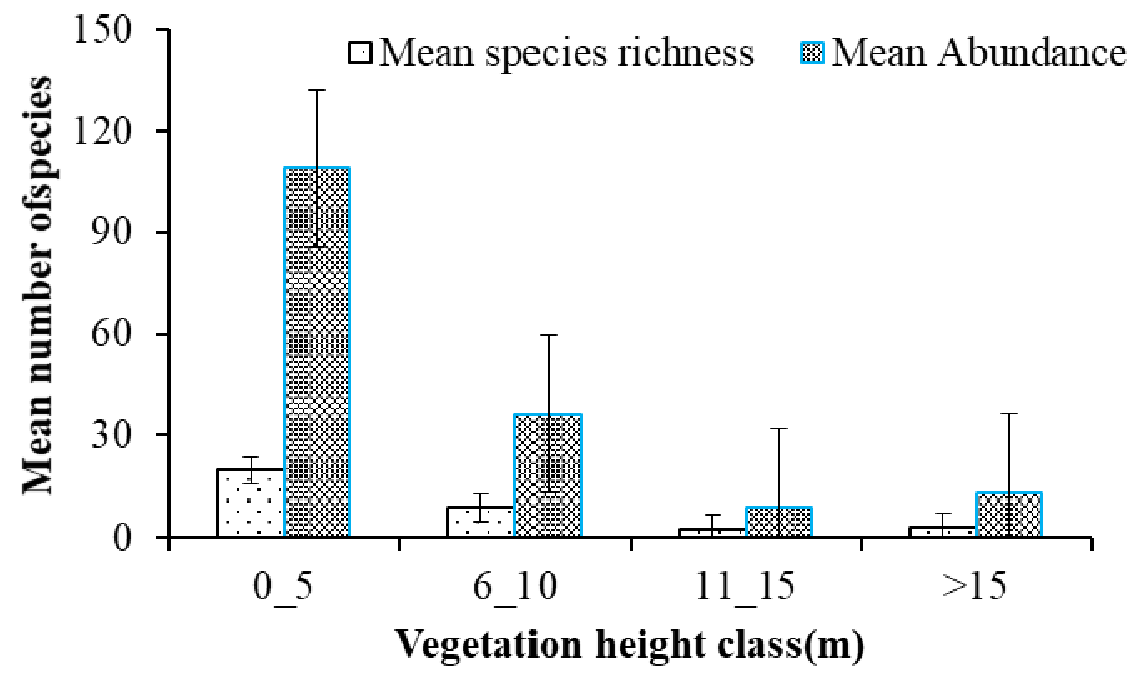

Figure 4. Mean species richness and abundance of birds across vegetation height classes of Nansebo forest.

In Nansebo forest, three models were eventually fitted that quantitatively and qualitatively explain which of the habitat components accounted for habitat association by the bird species. There was variation in habitat quality for both species richness and abundance during the wet and dry seasons. Average vegetation height was a good predictor for both bird species richness during dry season and bird species abundance during wet season, while altitude accounted for difference in bird species abundance during wet season in Nansebo forest (Table 2).

Table 2: Summary statistics for selected models that describe habitat association of birds in dry and wet seasons at Nansebo forest

The Durbin-Watson statistic (D-W) and Variance Inflation Factor (VIF) were used to examine autocorrelation and multicollinearity of the predictor variables.

\begin{tabular}{|c|c|c|c|c|c|c|c|c|c|}
\hline \multirow[b]{2}{*}{ Model } & \multirow[b]{2}{*}{ Habitat variable } & \multirow[b]{2}{*}{ Coefficient } & \multirow[b]{2}{*}{$\mathrm{p}$} & \multirow[b]{2}{*}{$\mathrm{F}$} & \multirow[b]{2}{*}{ VIF } & \multicolumn{4}{|c|}{ Overall model } \\
\hline & & & & & & $\mathrm{p}$ & $\mathrm{S}$ & $\mathrm{R}(\%)$ & D-W \\
\hline \multirow[t]{2}{*}{ BSRDS } & Constant & & & & & 0.002 & 0.858 & 4.5 & 1.19 \\
\hline & Av. Veg. height & & 0.006 & 0.033 & 1.00 & & & & \\
\hline \multirow[t]{3}{*}{ BSADS } & Constant & 20.701 & & & & 0.020 & 0.021 & 14.6 & 1.358 \\
\hline & Slope & 1.636 & 0.0631 & 0.164 & 1.00 & & & & \\
\hline & Av. Veg. height & -1.102 & 0.0767 & 0.850 & 1.00 & & & & \\
\hline \multirow[t]{2}{*}{ BSRWS } & Constant & 5.099 & & & & 0.0414 & 5.408 & 19.3 & 1.434 \\
\hline & Av. Veg. height & 0.533 & 0.060 & 0.700 & 1.000 & & & & \\
\hline \multirow[t]{3}{*}{ BSAWS } & Constant & 744.0 & & & & 0.001 & 0.583 & 76.3 & 1.219 \\
\hline & Av. Veg. height & 3.457 & 0.0020 & 11.880 & 1.103 & & & & \\
\hline & Altitude & -0.318 & 0.000 & & 1.103 & & & & \\
\hline \multirow[t]{3}{*}{ TSR } & Constant & 26.344 & & & 1.009 & 0.0183 & 0.092 & 30.4 & 1.452 \\
\hline & Av. Veg. height & 0.039 & 0.0912 & 1.781 & 1.009 & & & & \\
\hline & Altitude & -0.009 & 0.0710 & & & & & & \\
\hline \multirow[t]{3}{*}{ TBA } & Constant & 374.169 & & & 1.009 & 0.0017 & 0.208 & 45.6 & 1.057 \\
\hline & Av. Veg. height & 2.742 & 0.476 & 4.59 & 1.009 & & & & \\
\hline & Altitude & -0.157 & 0.007 & & & & & & \\
\hline
\end{tabular}

BSRDS: Bird species richness dry season

BSADS: Bird species abundance dry season

BSRWS: Bird species richness wet season

BSAWS: Bird species abundance wet season

TSR: Total species richness

TBA: Total species abundance

\section{DISCUSSION}

The relative abundance of bird species during seasons might also be related to the availability of food, habitat condition and breeding season of the species. Therefore, species distribution and abundance can be influenced by seasonal variation. Many factors could account for this. For example, Karr (1976) related the seasonality in the 
number of bird species with the availability of resources such as food and vegetation strata and found that the number of bird species varied seasonally with peaks in the late dry and early wet seasons.

In Nansebo, Abyssinian oriole (Oriolus monacha) had the highest percent relative abundance in Moist Afromontane forest. This was due to the favorable environment of the habitat that supported the species in different ways. Since, Oriolus monacha is a forest specialist species, it could be confined to the natural forest habitat types unlike many other species recorded from the area that tend to concentrate in heterogeneous human modified habitat ignoring the homogenous natural forest. Similar observation has been made in a study carried out in Tanzania, where by forest specialists were only confined to the homogenous forest ignoring the heterogeneous human modified habitat types (Casas, 2016).

Species similarity among vegetation types of the same season show highest value in more similar vegetation types in both seasons. The maximum value of species similarity between modified and Moist Afromontane forest of Nansebo forest is due to the nature of similarity in vegetation types the two habitat types could present equivalent foraging opportunities and nesting sites. This is in agreement with Estade (1997). He found a positive correlation between the occurrence of certain tree species and bird species. Therefore, similarity in floristic composition may account for the similarity in bird species between different vegetation types.

The difference in species diversity, number of species and number of individuals of species among the different habitat types of the present study could be associated with differences in habitat characteristics and feeding habits of birds as suggested by (St-Laurent et al., 2007). In Nansebo forest fruit trees, mainly croton macrostachys, Strychnos spinosa, Cordia Africana were observed to support a large number of species such as: Abyssinian oriole, Red-winged starling, and African paradise fly catcher, Greater honey guide, Streaky seed eater, Semi collared flycatcher and Cinnamon bracken warbler, Black winged love bird, Blue headed coucal and Common bulbul; whereas, Collared sunbird, Scarlet-chested sunbird, and Variable sunbird were associated with flower bearing trees, shrubs and vegetable gardens. These trees are far from being approached by predators, and human interference; and are also known to produce edible fruits. In addition, the large size of the Moist Afromontane forest and canopy cover helped to have an ideal habitat for the bird species.

In Nansebo, there was variation in species richness and abundance as vegetation height varies. Difference between average species richness and individuals and the vegetation height was significant in Nansebo forest. The numbers of vegetation associates at different height intervals were indicative of vegetation density that was related with bird diversity. Many researchers have written differently on the relationship between bird diversity and vegetation types. MacArthur and his followers stated that vegetation type and structure is more closely connected to bird species diversity than floristic composition (MacArthur, 1964).

As the vegetation layer increases, the number of available niches for birds also increases and so does the diversity of avian species. This is due to the different feeding habit of birds leading to niche separation (MacArthur, 1964).

Primary topographic factors (eg. Slope, aspect, elevation) alter micro climatic conditions and indirectly affect the growth and distribution of land cover (vegetation), hence affecting bird distribution and abundance. This in line with McCain (2009) and Rahbek(2005) that reported general decrease in species richness and abundance along the elevation gradient.

The decrease in abundance and species richness as vegetation height increases could be as a result of decrease in heterogeneity in habitat type, absence of fruiting trees and risk of predation that could be higher in natural forest. Other study support this, as birds were more abundant in heterogeneous habitats than homogenous forest (Pennington and Blair, 2011; Shochat et al., 2010).

\section{CONCLUSION AND RECOMMENDATIONS}

The Nansebo forest is the most important habitat for birds to nest, breed, shelter and feed as well as habitat for different animals. However, its species composition, diversity, abundance and distribution vary both seasonally and habitat wise. This can be associated with the individual species response to vegetation characteristics such as vegetation height, cover and feeding behavior in addition to seasonality such as change in availability of moisture and temperature. Birds in this habitat also differ with reference to habitat characteristics

The data collected provide valuable information on the ecology of birds and their significance for the environment. Conserving the habitats as well as the species has great biological and social values. Therefore, community-based conservation should be carried out to implant the sense of ownership in the minds of the local people.

Therefore, unless action is taken, these disturbance-sensitive bird species will suffer more on their survival. Additional detailed studies on bird species together with the other ecological aspects of the avians should be conducted.

\section{ACKNOWLEDGEMENT}

We are grateful to Almighty Allah who has helped us to accomplish this study. Our gratitude also goes to 
Wondo Genet College of Forestry and Natural Resources, Hawassa University for funding this research

\section{REFERENCES}

Aerts, R., F. Lerouge, E. Novmber, L. Lens, M. Hermay and B. Muys. 2008. Land rehabilitation and the conservation of birds in a degraded Afromontane landscape in northern Ethiopia.Biodiversity and Conservation 17: 53-69.

Afework Bekele and Shimelis Aynalem. 2009. Species composition, relative abundance and habitat association of the bird fauna of the montane forest of Zegie Peninsula and nearby Islands, Lake Tana, Ethiopia. SINET: Ethiopian Journal of Science 32:45-56.

Bibby, C. J., Burgess, N. D and D. Hills. 1992. Birds census technique. Tokyo, Toronto. Academic press 30: 8696.

Bibby, C.J., S. Marsden, and M. Jones. 1998. Bird surveys. Expedition Advisory Centre.

Buckley, H.L. and. R. P. Freckle ton. 2010. Understanding the role of species dynamics in abundance occupancy relationships.Journal of Ecology 98: 645-658.

Casas, G., B. Darski, P. M. A. Ferreira, A. Kindel and S. C. Müller. 2016. Habitat structure influences the diversity, richness and composition of bird assemblages in successional Atlantic rain forest. Tropical Conservation Science 9: 503-524

Chance, J.F., and J. Walsh . 2006. Urban effects on native avifauna: A review. Landscape Urban Plan 74:46-69.

Clout, M.N. and J.R. Hay. 1989. The importance of birds as browsers, pollinators and seed dispersers in New Zealand forest.New Zealand journal of ecology.27-33.

ECSA. 2007. National census conducted by Ethiopian central statistical agency. Addis Ababa ,Ethiopia.

Girma Mengesha and Afework Bekele. 2008. Diversity and relative abundance of birds of Alatish National Park. International Journal of Ecology and Environmental Sciences 34:215-222.

Girma Mengesha, Yosef Mamo and Afework Bekele. 2011. A comparison of terrestrial bird community structure in the undisturbed and disturbed areas of the Abijata Shalla lakes national park, Ethiopia. International Journal of Biodiversity and Conservation 3:389-404.

Jacobs, M.J. and Schloeder, C.A. (2001). Impacts of Conflict on Biodiversity and Protected Areas in Ethiopia. World Wildlife Fund Inc., Washington D.C.

Karr, J.R. 1976. Seasonality resource availability and community diversity in tropical bird communities. The American Naturalist 110: 937-974.

Kent, M. and P. Coker. 1992. Vegetation Description and Analysis: Ambo Practical approach. Bent Haven Press,New York.

Lee, P.Y. and J.T. Rotenberry. 2005. Relationships between bird species and tree species assemblages in forested habitats of north eastern America. Journal of Biogeography 32:1139-1150..

MacArthur, R.H. 1964. Environmental factors affecting bird species diversity. American Naturalist 98: 387-397.

McCain, C. M. 2009. Global analysis of bird elevation diversity.Global Ecology and Biogeography 18: 346-360.

NWAO. 2012. Annual Report. 18-25.

NWCTO. 20014. Annual Report. 13-17.

Pennington, D.N and R.B. Blair. 2011. Habitat selection of breeding riparian birds in an urban environment: Untangling the relative importance of biophysical element and spatial scale. Diversity and distribution 17: $506-518$.

Rahbek, C. 2005. The role of spatial scale and the perception of large-scale species-richness patterns. Ecological Letters 8: 224-239.

Rodríguez-Estrella, R. 2007 . Land use changes affect distributional patterns of desert birds in the Baja California peninsula, Mexico. Diversity and distribution 13: 877-889.

Sekercioglu, C. 2012. Bird functional diversity and ecosystem services in tropical forest, agro forest and agricultural areas. Journal of Ornithology 153:153-161.

Shochat, E., S. Lerman and E. Fernández-Juricic. 2010. Birds in urban ecosystems: Population dynamics, community structure, biodiversity, and conservation. Urban Ecosystem Ecology 55:75-86.

Sisay Hailu. 2008. Species composition, distribution, relative abundance and habitat association of Avifauna of Wof washa National Forestry Priority Area, Ethiopia. M.Sc Thesis (unpublished), Addis Ababa University. 76-87.

St-Laurent, M.H., Ferron, J., C. Hins and R. Gagnon. 2007. Effects of stand structure and landscape characteristics on Habitat association by birds and small mammals in managed boreal forest of eastern Canada. Canadian Journal of Forest Research 37: 1298-1309.

Tees, J., U. Brose, V. Grimm, K. Tielborger, M.C . Wichmann, M. Schwagen, and F. Jeltsch. 2004. Animal species diversity driven by habitat heterogeneity/diversity: the importance of keystone structures. Journal of Biogeograph 31:79-92.

Weldemariam Tesfahunegny Bezabh. 2006. A guide to a complete annotated checklist of the birds of Ethiopia. 
Yalden, D.W. and Largen, M.J. (1992). The endemic mammals of Ethiopia. Mamm. Rev. 22:115-150.

Zerihun Girma, George Chuyong, Paul Evangelista and Yosef Mamo. 2015. Habitat Characterization and Preferences of the Mountain Nyala (Tragelaphus Buxtoni, Lydekker 1910) and Menelik's Bushbuck (Tragelaphus Scriptus Meneliki, Neumann 1902) in Arsi Mountains National Park, South-Eastern Ethiopia. International Journal of Current Research 7: 23074-23082.

Appendix 1: Bird species recorded at Nansebo forest (a, Near Endemic c, endangered b, Endemic e, near threatened NM, Northern Migratory AM, Inter-African migrant)

\begin{tabular}{|c|c|c|c|c|c|c|c|c|}
\hline \multirow[t]{2}{*}{ Order } & \multirow[t]{2}{*}{ Family } & \multirow[t]{2}{*}{ Common Name } & \multirow[t]{2}{*}{ Scientific Name } & \multicolumn{3}{|c|}{ Abundance } & \multirow[b]{2}{*}{ RA (\%) } & \multirow[b]{2}{*}{ Rank } \\
\hline & & & & Wet & Dry & Total & & \\
\hline Passeriformes & Oriolidae & Abyssinian oriole & Oriolus monacha $a^{\mathbf{a}}$ & 68 & 46 & 74 & 6.9 & $1^{\text {st }}$ \\
\hline Passeriformes & Turdidae & Mountain thrush & Turdus olivaceus & 34 & 14 & 48 & 4.5 & $2^{\text {nd }}$ \\
\hline Passeriformes & Zosteropidae & Montane white eye & Zosterops poliogastrus & 23 & 12 & 35 & 3.3 & $3^{\text {rd }}$ \\
\hline Passeriformes & Passeridae & Swaisons sparrow weaver & Passer swainsonii & 22 & 11 & 33 & 3.1 & $4^{\text {th }}$ \\
\hline Passeriformes & 'Sturnidae & Red winged starling & Onychognathus morio & 17 & 13 & 30 & 2.8 & $5^{\text {th }}$ \\
\hline Passeriformes & Fringillidae & Streaky seed eater & Serinus striolatus & 22 & 7 & 29 & 2.7 & $6^{\text {th }}$ \\
\hline Passeriformes & Estrildidae & Yellow bellied waxbill & Coccopygia quartinia & 19 & 10 & 29 & 2.7 & $6^{\text {th }}$ \\
\hline Passeriformes & ploceidae & Baglafecht weaver & Ploceus baglafecht & 16 & 7 & 26 & 2.4 & $8^{\text {th }}$ \\
\hline Passeriformes & Oriolidae & Black headed oriole & Oriolus larvatus & 13 & 3 & 26 & 2.4 & $8^{\text {th }}$ \\
\hline Passeriformes & Muscicapidae & Abyssinian slaty flycatcher & Melaenornis chocolatina ${ }^{\mathbf{a}}$ & 16 & 9 & 25 & 2.3 & $10^{\text {th }}$ \\
\hline Passeriformes & Muscicapidae & Semi collared flycatcher & Ficedula semitorquata $^{\mathbf{e}}$ & 22 & 3 & 25 & 2.3 & $10^{\text {th }}$ \\
\hline Passeriformes & Nectariniidae & Variable sun bird & Cinnyris venustus & 16 & 7 & 23 & 2.1 & $12^{\text {th }}$ \\
\hline Passeriformes & 'Pycnonotidae & Common bulbul & Pycnonotus barbatus & 12 & 10 & 22 & 2.1 & $12^{\text {th }}$ \\
\hline Trogoniformes & Trogonidae & Narina's Trogon & Apaloderma narina & 15 & 5 & 20 & 1.9 & $14^{\text {th }}$ \\
\hline Passeriformes & Viduidae & Pin tailed whydah & Vidua macroura & 16 & 4 & 20 & 1.9 & $14^{\text {th }}$ \\
\hline Passeriformes & Muscicapidae & Rupels robin chat & Cossypha semirufa & 11 & 9 & 20 & 1.9 & $14^{\text {th }}$ \\
\hline Passeriformes & Corvidae & Thick billed raven & Corvus crassirostris $^{\mathbf{a}}$ & 12 & 7 & 19 & 1.8 & $17^{\text {th }}$ \\
\hline Piciformes & Indicatoridae & Greater honey guide & Indicator indicator & 16 & 2 & 18 & 1.7 & $17^{\text {th }}$ \\
\hline Passeriformes & Estrildidae & Red billed fire finch & Lagonosticta senegala & 14 & 4 & 18 & 1.7 & $17^{\text {th }}$ \\
\hline Passeriformes & Monarchidae & African dusky flycatcher & Muscicapa adusta & 9 & 7 & 16 & 1.5 & $20^{\text {th }}$ \\
\hline Passeriformes & Sylviidae & Cinnamon bracken warbler & Bradypterus cinnamomeus & 14 & 2 & 16 & 1.5 & $20^{\text {th }}$ \\
\hline Passeriformes & Fringillidae & African citril & Serinus citrinelloides & 9 & 6 & 15 & 1.4 & $22^{\text {th }}$ \\
\hline Galliformes & phasianidae & Chestnut naped francolin & Pternistis castaneicollis & 11 & 4 & 15 & 1.4 & $22^{\text {th }}$ \\
\hline Passeriformes & Cisticolidae & Ethiopian cisticola & Cisticola lugubris $^{\mathbf{a}}$ & 13 & 2 & 15 & 1.4 & $22^{\text {th }}$ \\
\hline Passeriformes & Cisticolidae & Green backed cameroptera & Camaroptera brachyura & 6 & 9 & 15 & 1.4 & $22^{\text {th }}$ \\
\hline Psittaciformes & Psittaculidae & Black winged love bird & Agapornis taranta $^{\mathrm{a}}$ & 10 & 4 & 14 & 1.3 & $26^{\text {th }}$ \\
\hline Psittaciformes & Nectariniidae & Collared sun bird & Hedydipna collaris & 12 & 2 & 14 & 1.3 & $26^{\text {th }}$ \\
\hline Columbiformes & Columbidae & Red eyed dove & Strepetopelia semitorquata & 10 & 4 & 14 & 1.3 & $26^{\text {th }}$ \\
\hline Passeriformes & Monarchidae & *African paradise flycatcher ${ }^{\mathbf{A M}}$ & Terpsiphone viridis & 9 & 4 & 13 & 1.2 & $29^{\text {th }}$ \\
\hline Passeriformes & Fringillidae & Brown rumped seed eater & Crithagra tristriatus & 8 & 5 & 13 & 1.2 & $29^{\text {th }}$ \\
\hline Piciformes & Indicatoridae & Lesser honeyguide & Indicator minor & 9 & 4 & 13 & 1.2 & $29^{\text {th }}$ \\
\hline Accipitriformes & Accipitridae & Lesser spotted eagle & Aquila pomarina & 8 & 4 & 12 & 1.1 & $32^{\text {th }}$ \\
\hline Cuculiformes & Cuculidae & *Levaillant's cuckoo ${ }^{\mathbf{A M}}$ & Clamator levaillantii & 9 & 2 & 11 & 1.0 & $33^{\text {th }}$ \\
\hline Passeriformes & Fringillidae & Yellow crowned canary & Crithagra mozambicus & 11 & 0 & 11 & 1.0 & $33^{\text {th }}$ \\
\hline Passeriformes & Cisticolidae & Tawny flanked prinia & Prinia subflava & 6 & 4 & 10 & 0.9 & $35^{\text {th }}$ \\
\hline Cuculiformes & Musophagidae & White cheeked turaco & Tauraco leucotis & 4 & 6 & 10 & 0.9 & $35^{\text {th }}$ \\
\hline Piciformes & Picidae & Abyssinian wood pecker & Dendropicos abyssinicus & 4 & 5 & 9 & 0.8 & $37^{\text {th }}$ \\
\hline Passeriformes & Sylviidae & Brown wood warbler & Phylloscopusumbrovirens ${ }^{\mathbf{a}}$ & 7 & 2 & 9 & 0.8 & $37^{\text {th }}$ \\
\hline Passeriformes & Laniidae & Common fiscal & Lanius collaris & 7 & 2 & 9 & 0.8 & $37^{\text {th }}$ \\
\hline Coliiformes & Collidae & Speckled mouse bird & Colius striatus & 5 & 4 & 9 & 0.8 & $37^{\text {th }}$ \\
\hline Psittaciformes & Psittacidae & Yellow fronted parrot & Poicephalusflavifrons $\mathbf{b}$ & 7 & 2 & 9 & 0.8 & $37^{\text {th }}$ \\
\hline Passeriformes & Passeridae & Bush petronia & Petronia dentata & 6 & 2 & 8 & 0.7 & $42^{\text {th }}$ \\
\hline Columbiformes & Columbidae & Dusky turtle dove & Streptope lialugens & 2 & 6 & 8 & 0.7 & $42^{\text {th }}$ \\
\hline Passeriformes & Buphagidae & Red billed oxpecker & Buphagus erythrorhynchus & 4 & 4 & 8 & 0.7 & $42^{\text {th }}$ \\
\hline Piciformes & Indicatoridae & Scaly throated honey guide & Indicator variegatus & 8 & 0 & 8 & 0.7 & $42^{\text {th }}$ \\
\hline Coraciiformes & Alcedinidae & Wood land kingfisher & Halcon senegalensis & 3 & 5 & 8 & 0.7 & $42^{\text {th }}$ \\
\hline Passeriformes & Sylviidae & Wood warbler & Phylloscopus sibilatrix & 6 & 2 & 8 & 0.7 & $42^{\text {th }}$ \\
\hline Falconiformes & Accipitridae & Augur buzzard & Buteo augur & 4 & 3 & 7 & 0.7 & $42^{\text {th }}$ \\
\hline Cuculiformes & Sylviidae & Brown parisoma & Parisoma lugens & 5 & 2 & 7 & 0.7 & $42^{\text {th }}$ \\
\hline Piciformes & Picidae & Eastern grey wood pecker & Dendropicos goertae & 5 & 2 & 7 & 0.7 & $42^{\text {th }}$ \\
\hline Piciformes & Picidae & Nubian wood pecker & Campethera nubica & 5 & 2 & 7 & 0.7 & $42^{\text {th }}$ \\
\hline Columbiforme & Columbidae & $*$ Tambourine dove ${ }^{\mathrm{AM}}$ & Turtur tympanistria & 6 & 1 & 7 & 0.7 & $42^{\text {th }}$ \\
\hline Cuculiformes & Cuculidae & African emerald cuckoo & Chrysococcyx cupreus & 4 & 2 & 6 & 0.6 & $53^{\text {th }}$ \\
\hline Piciformes & Lybiidae & Banded barbet & Lybius undatus ${ }^{\mathrm{a}}$ & 3 & 3 & 6 & 0.6 & $53^{\text {th }}$ \\
\hline Passeriformes & Hirundinidae & *Barn swallow ${ }^{\mathrm{NM}}$ & Hirundo rustica & 2 & 4 & 6 & 0.6 & $53^{\text {th }}$ \\
\hline Passeriformes & Sylviidae & Black start & Cercomela melanura & 6 & 0 & 6 & 0.6 & $53^{\text {th }}$ \\
\hline Passeriformes & Estrildidae & Common waxbill & Estrilda astrild & 6 & 0 & 6 & 0.6 & $53^{\text {th }}$ \\
\hline Passeriformes & Buphagidae & Grey cuckoo shrike & Coranica caesia & 4 & 2 & 6 & 0.6 & $53^{\text {th }}$ \\
\hline Passeriformes & Turdidae & Ground scraper thrush & Psophocichla litsipsirupa & 4 & 2 & 6 & 0.6 & $53^{\text {th }}$ \\
\hline Passeriformes & Sylviidae & Little rush warbler & Bradypterus baboecala & 4 & 2 & 6 & 0.6 & $53^{\text {th }}$ \\
\hline Passeriformes & Muscicapidae & Northern black flycatcher & Melaenornis edolioides & 6 & 0 & 6 & 0.6 & $53^{\text {th }}$ \\
\hline Coraciiformes & Coraciidae & Abyssinian roller & Coracias abyssinicus & 5 & 0 & 5 & 0.5 & $53^{\text {th }}$ \\
\hline Apodiformes & Apodidae & African black swift & Apus barbatus & 3 & 2 & 5 & 0.5 & $53^{\text {th }}$ \\
\hline Columbiformes & Columbidae & Black billed wood dove & Turtur abyssinicus & 4 & 1 & 5 & 0.5 & $53^{\text {th }}$ \\
\hline Passeriformes & Buphagidae & Black cuckoo shrike & Campephaga flava & 3 & 2 & 5 & 0.5 & $53^{\text {th }}$ \\
\hline Accipitriformes & Buphagidae & Lesser white throat & Sylvia curruca & 5 & 0 & 5 & 0.5 & $53^{\text {th }}$ \\
\hline Cuculiformes & Cuculidae & Red chested cuckoo & Cuculus solitarius & 5 & 0 & 5 & 0.5 & $53^{\text {th }}$ \\
\hline Passeriformes & Cisticolidae & Red faced cisticola & Cisticola erythrops & 3 & 2 & 5 & 0.5 & $53^{\text {th }}$ \\
\hline Ciconiiformes & Threskiornithidae & Silvery checked hornbill & Bycanistes brevis & 3 & 5 & 5 & 0.5 & $53^{\text {th }}$ \\
\hline Cuculiformes & Paridae & White winged black tit & Parus leucomelas & 4 & 1 & 5 & 0.5 & $53^{\text {th }}$ \\
\hline Accipitriformes & Cisticolidae & Yellow breasted apalis & Apalis flavida & 5 & 0 & 5 & 0.5 & $53^{\text {th }}$ \\
\hline
\end{tabular}




\begin{tabular}{|c|c|c|c|c|c|c|c|c|}
\hline \multirow[t]{2}{*}{ Order } & \multirow[t]{2}{*}{ Family } & \multirow[t]{2}{*}{ Common Name } & \multirow[t]{2}{*}{ Scientific Name } & \multicolumn{3}{|c|}{ Abundance } & \multirow[b]{2}{*}{ RA (\%) } & \multirow[b]{2}{*}{ Rank } \\
\hline & & & & Wet & Dry & Total & & \\
\hline Pelecaniformes & Timaliidae & Abyssinian cat bird & Parophasma galinieri $^{\mathbf{b}}$ & 3 & 1 & 4 & 0.4 & $72^{\text {th }}$ \\
\hline Piciformes & Lybiidae & Black billed barbet & Lybius guifsobalito & 4 & 0 & 4 & 0.4 & $72^{\text {th }}$ \\
\hline Columbiformes & Columbidae & Ring necked dove & Streptopelia capicola & 2 & 2 & 4 & 0.4 & $72^{\text {th }}$ \\
\hline Accipitriformes & Accipitridae & Rupels vulture & Gyps rueppellii & 0 & 4 & 4 & 0.4 & $72^{\text {th }}$ \\
\hline Falconiformes & Accipitridae & *Tawny eagle ${ }^{\mathbf{M}}$ & Aquila rapax & 3 & 1 & 4 & 0.4 & $72^{\text {th }}$ \\
\hline Pelecaniformes & Threskiornithidae & Wattled ibis & Bostrychia carunculata & 2 & 2 & 4 & 0.4 & $72^{\text {th }}$ \\
\hline Falconiformes & Accipitridae & White backed vulture & Gyps africanus & 4 & 0 & 4 & 0.4 & $72^{\text {th }}$ \\
\hline Passeriformes & Sylviidae & Willow warbler & Phylloscopus trochilus & 0 & 4 & 4 & 0.4 & $72^{\text {th }}$ \\
\hline Passeriformes & Cisticolidae & Buff-bellied warbler & Phyllolais pulchella & 0 & 3 & 3 & 0.3 & $80^{\text {th }}$ \\
\hline Passeriformes & Sylviidae & Dark caped yellow warbler & Chloropeta natalensis & 2 & 1 & 3 & 0.3 & $80^{\text {th }}$ \\
\hline Passeriformes & Motacillidae & *Yellow wagtail $^{\mathrm{NM}}$ & Motacilla flava & 3 & 0 & 3 & 0.3 & $80^{\text {th }}$ \\
\hline Passeriformes & Estrildidae & African fire finch & Lagonosticta rubricata & 0 & 2 & 2 & 0.2 & $81^{\text {th }}$ \\
\hline Columbiformes & Columbidae & African olive pegion & Columba arquatrix & 0 & 2 & 2 & 0.2 & $81^{\text {th }}$ \\
\hline Coraciiformes & Alcedinidae & African pigmy kingfisher & Ceyx pictus & 2 & 0 & 2 & 0.2 & $81^{\text {th }}$ \\
\hline Passeriformes & Sylviidae & *Black cap ${ }^{\mathrm{NM}}$ & Sylvia atricapilla & 0 & 2 & 2 & 0.2 & $81^{\text {th }}$ \\
\hline Piciformes & Platysteiridae & Black headed batis & Batis minor & 0 & 2 & 2 & 0.2 & $81^{\text {th }}$ \\
\hline Columbiformes & phoeniculidae & Black- billed wood hoopoe & Phoeniculus somaliensis & 2 & 0 & 2 & 0.2 & $81^{\text {th }}$ \\
\hline Cuculiformes & Cuculidae & Blue headed coucal & Centropus monachus & 0 & 2 & 2 & 0.2 & $81^{\text {th }}$ \\
\hline Passeriformes & Sylviidae & $*$ Common redstart $^{\mathrm{NM}}$ & Phoeniculus phoenicurus & 2 & 0 & 2 & 0.2 & $81^{\text {th }}$ \\
\hline Coraciiformes & Bucerotidae & Crowned hornbill & Tockus alboterminatus & 2 & 0 & 2 & 0.2 & $81^{\text {th }}$ \\
\hline Columbiformes & Threskiornithidae & Hadada ibis & Bostrychia hagedash & 2 & 0 & 2 & 0.2 & $81^{\text {th }}$ \\
\hline Passeriformes & 'Malaconotidae & Northern puff back & Dryoscopus gambensis & 0 & 2 & 2 & 0.2 & $81^{\text {th }}$ \\
\hline Passeriformes & Nectariniidae & Takazze sun bird & Nectarinia tacazze & 0 & 2 & 2 & 0.2 & $81^{\text {th }}$ \\
\hline Ciconiiformes & Ciconiidae & Woolly-necked stork & Ciconia episcopus & 0 & 2 & 2 & 0.2 & $81^{\text {th }}$ \\
\hline Passeriformes & Turdidae & Abyssinian ground thrush & Zoothera piaggiae & 0 & 1 & 1 & 0.1 & $96^{\text {th }}$ \\
\hline Falconiformes & strigidae & Cape eagle owl & Bubo capensis & 0 & 1 & 1 & 0.1 & $96^{\text {th }}$ \\
\hline Passeriformes & Corvidae & Fan tailed raven & Corvus rhipidurus & 1 & 0 & 1 & 0.1 & $96^{\text {th }}$ \\
\hline Falconiformes & strigidae & Greyish eagle owl & Bubo cinerascens & 1 & 0 & 1 & 0.1 & $96^{\text {th }}$ \\
\hline Pelecaniformes & Ardeidae & Little egret & Egretta garzetta & 0 & 1 & 1 & 0.1 & $96^{\text {th }}$ \\
\hline Accipitriformes & Accipitridae & Lizzard buzzard & Kaupifalco monogrammicus & 0 & 1 & 1 & 0.1 & $96^{\text {th }}$ \\
\hline Passeriformes & Muscicapidae & Mocking cliff chat & Thamnolaea cinnamomeiventris & 1 & 0 & 1 & 0.1 & $96^{\text {th }}$ \\
\hline Columbiformes & Columbidae & Namaqua dove & Oena capensis & 0 & 1 & 1 & 0.1 & $96^{\text {th }}$ \\
\hline Accipitriformes & Accipitridae & Pallied harrier ${ }^{\mathrm{NM}}$ & Circus macrourus & 0 & 1 & 1 & 0.1 & $96^{\text {th }}$ \\
\hline Accipitriformes & Accipitridae & Yellow billed kite & Milvus(migrans) aegyptius & 0 & 1 & 1 & 0.1 & $96^{\text {th }}$ \\
\hline
\end{tabular}

